\title{
Correction to: Roles of tumor-associated macrophages in tumor progression: implications on therapeutic strategies
}

Shuangli Zhu', Ming Yi ${ }^{1}$, Yuze $\mathrm{Wu}^{1}$, Bing Dong ${ }^{2^{*}}$ and Kongming $\mathrm{Wu}^{1,2^{*}}$ (D)

\section{Correction to: Experimental Hematology \& Oncology (2021) 10:60 https://doi.org/10.1186/s40164-021-00252-z}

Following publication of the original article [1], the author reported error in first author name. The first author name was misspelling in the submitted version and published as Shangli Zhu. The correct version is "Shuangli Zhu".

The original article has been corrected.

Published online: 03 February 2022

\section{Reference}

1. Zhu S, Yi M, Wu Y, Dong B, Wu K. Roles of tumor-associated macrophages in tumor progression: implications on therapeutic strategies. Exp Hematol Oncol. 2021;10(1):60. https://doi.org/10.1186/s40164-021-00252-z.

\section{Publisher's Note}

Springer Nature remains neutral with regard to jurisdictional claims in published maps and institutional affiliations.

*Correspondence: dongbing2015@126.com; wukm_lab@163.com

1 Department of Oncology, Tongji Hospital of Tongji Medical College, Huazhong University of Science and Technology, Wuhan 430030, China

${ }^{2}$ Department of Molecular Pathology, The Affiliated Cancer Hospital of Zhengzhou University \& Henan Cancer Hospital, Zhengzhou 450008,

China

(c) The Author(s) 2022. Open Access This article is licensed under a Creative Commons Attribution 4.0 International License, which permits use, sharing, adaptation, distribution and reproduction in any medium or format, as long as you give appropriate credit to the original author(s) and the source, provide a link to the Creative Commons licence, and indicate if changes were made. The images or other third party material in this article are included in the article's Creative Commons licence, unless indicated otherwise in a credit line to the material. If material is not included in the article's Creative Commons licence and your intended use is not permitted by statutory regulation or exceeds the permitted use, you will need to obtain permission directly from the copyright holder. To view a copy of this licence, visit http://creativecommons.org/licenses/by/4.0/. The Creative Commons Public Domain Dedication waiver (http://creativecommons.org/publicdomain/zero/1.0/) applies to the data made available in this article, unless otherwise stated in a credit line to the data. 